AGRO EKONOMI, Vol 30, Issue 2, December 2019, Page.110-124

DOI : http://doi.org/10.22146/ae.48869

ISSN 0215-8787 (print), ISSN 2541-1616 (online)

Available at https://jurnal.ugm.ac.id/jae/

\title{
FARMERS' WILLINGNESS TO ACCEPT A COMPENSATION TO PROTECT AGRICULTURAL LAND SUSTAINABILITY IN PERI-URBAN AREAS OF PEKALONGAN CITY
}

\author{
Imade Yoga Prasada ${ }^{1}$, Masyhuri ${ }^{2}$ \\ ${ }^{1,2}$ Agricultural Economics, Faculty of Agriculture, Universitas Gadjah Mada, \\ Yogyakarta \\ Jl. Flora No.1, Bulaksumur, Sleman, Daerah Istimewa Yogyakarta \\ imade.yogap@gmail.com
}

Submitted : 19 August 2019 ; Revised : 4 September 2019;

Accepted : 29 September 2019

\begin{abstract}
Agricultural land is a land that has a relatively low rental value, so agricultural land is very vulnerable to be converted. Therefore, this research was conducted with the aim 1) to know farmers' willingness to accept a compensation to protect agricultural land sustainability, 2) to know the factors that influence farmers' willingness to accept / reject WTA, and 3) to know the factors that influence the WTA value of farmers' in the peri-urban areas. The study was conducted in the peri-urban areas of Pekalongan City. The research respondents were 90 farmer owners and cultivators. The research data was analyzed by using Heckman's twostage model. The results show that farmers' WTA in the peri-urban areas of Pekalongan City amounted to IDR 7,217,827.27 per year. Factors that influence farmers' willingness to accept or reject compensation were the distance of the agricultural land to the main road and farmers' perceptions toward the sustainability of agricultural land in the peri-urban areas. Factors influencing the number of farmers' WTA to be willing to protect the agricultural land in the peri-urban areas of Pekalongan City were farmers' farm income and farming experience of the farmers. Sustainability of agricultural land in the suburbs of Pekalongan City can be maintained by taking into account the facilities and infrastructure needed by farmers who own agricultural land both far and close to the main road, increasing farmers' perceptions of the sustainability of agricultural land, increasing farm income and reducing the risk of farming production.
\end{abstract}

Keywords: farmers' willingness to accept; Heckman's two-stage model; Pekalongan City; periurban areas; sustainability of agricultural land

Prasada, I.Y \& Masyhuri (2019) Farmers' Willingness to Accept A Compensation to Protect Agricultural Land Sustainability in Peri-Urban Areas of Pekalongan City. Agro Ekonomi 30(2), $110-124$.

\section{INTRODUCTION}

Urban areas are very synonymous with a region that has a very high level of economic growth. The high economic growth in urban areas is supported by the high role of the industry and trade sectors that support the economy in urban areas. The relatively high economic growth in urban areas is an incentive for residents in rural areas to 
move and seek fortune in urban areas, so in this case it triggers an increasingly urbanization flow (Chen et al., 2014). The increasing urbanization has an impact on increasing population in urban areas (Guneralp et al., 2017).

The increase of population in urban areas has triggered an increase in the need of housing land (Jiang \& Zhang, 2016). In addition, the increase of economic activity in the urban area caused by the non-agricultural sector has led to the economic transformation of urban areas and an increase in land requirements for the non-agricultural sector in urban areas (Gardi et al., 2015; Yasar \& Siwar, 2016). An increase in land requirements for a need can only be fulfilled at the expense of land use for other needs. To meet the need when there is an increase in the need for land from the non-agricultural sector can only be done by adjusting the expense of the land used for activities in the agricultural sector or other sectors. It then causes a trade-off on land use in an area (Ghazouani, 2013). Trade-offs are expressed as opportunity costs which are the preferred alternative when making economic decisions, coming from the idea that resources are scarce, meaning that obtaining more than one scarce resource, individuals or groups collectively has to sacrifice a number of the other rare items (Xiangzheng et al.,
2016). Therefore, the trade-off of land use can have an impact on increasing one service from a particular sector and at the same time there will be a decrease in some services in other sectors.

Trade-offs of land use also occur with agricultural land, especially agricultural land in the peri-urban areas. Agricultural land has relatively low rental value compared to other economic activities, so it is vulnerable to be converted into non-agricultural land. The conversion of agricultural land will trigger an increasing risk of food security for the residents in urban areas (Aragie \& Genanu, 2017; Szabo, 2016). The conversion of agricultural land occuring in urban areas over time will increasingly expand towards the periurban areas due to the expansion of the urban area (Sudirman, 2012). This is a threat to the sustainability of agricultural land in the peri-urban areas. The threat to the sustainability of agricultural land is increasing along with the increasing number of degraded agricultural lands, rapid population growth and changes in economic structure and urbanization. Furthermore, it also triggers the decreasing amount of availability of agricultural labor (Pham etal., 2015; Sun \& Akiyama, 2018).

Studies in Kenya related to farmers' WTA using a logistic model, involve factors that positively influence WTA 
such as experience factors, perceptions of the PES program, and income level, while the factors that negatively influence WTA consist of education level, basic work, and interest in conservation activities (Nyongesa etal., 2016). Research in China concluded that farmers with a higher level of attention and awareness on the environmental conditions of paddy fields in Lake Poyang tend to have WTA values for lower ecological compensation (Jiaran et al., 2018). Research in Brazil concluded that farmers' decision to receive environmental services was influenced by farmers' perceptions of their environmental conditions (Motta \& Ortiz, 2018).

The previous research was carried out involving WTA in different case studies. In this study, farmers' WTA will be assessed to determine the willingness of farmers to protect their agricultural land that is owned and managed in the peri-urban areas of Pekalongan City. In addition, the analysis tool used in the previous study was the OLS model, while in this study, the two-stage Heckman model approach was used to determine the factors that influence farmers' decisions to receive or reject a compensation (WTA) and factors that influence the value of farmers' WTA in the peri-urban areas of Pekalongan City. Over the last few decades, urban areas, especially urban areas of Pekalongan
City, have experienced agricultural land conversion. Data from the Central Bureau Statistics of Pekalongan City shows that there has been a conversion of agricultural land by $33.79 \%$ in the period 1989 to 2015 in the City of Pekalongan (BPS, 2018). Research related to the conversion of paddy fields in Indonesia also concluded that over the past three decades, Indonesia has experienced conversion of paddy fields reaching an average of 8,346.65 ha / year in Java, and outside Java conversion of paddy fields to an average of 2,269.75 ha / year (Purbiyanti et al., 2017). The conversion of agricultural land has the potential to be expanded towards the suburbs of the city as a result of the phenomenon of urban sprawl in urban areas. Therefore, this research was conducted with the aim 1) to measure the WTA value of farmers to be willing to protect the sustainability of agricultural land in the peri-urban areas of Pekalongan City, 2) to determine the factors that influence farmers' decision to reject / accept WTA, and 3 ) to determine the factors that affect the value of farmers' WTA in the peri-urban areas of Pekalongan City.

\section{METHODS}

The research location was sited in the peri-urban areas of Pekalongan City, Central Java Province. The periurban areas of Pekalongan City were 
determined as the location of the study by using the purposive sampling method. The reason for the peri-urban areas of Pekalongan City was chosen is because Pekalongan City experienced massive and consistent conversion of agricultural land from 1989 to 2017 (BPS, 2018). The number of respondents in this study was determined by using the Slovin formula as follows (Haryanto et al., 2018).

$$
n=\frac{N}{1+N e^{2}}
$$

Where: $\mathrm{n}=$ Number of samples; $\mathrm{N}$ $=$ Total population; $\mathrm{e}=$ Margin of error

In this study, the population of farmer owners and cultivators in the peri-urban areas of Pekalongan City was 849 people. Based on the total population, the margin of error used was $10 \%$, and then the number of samples in this study was 90 farmer respondents. Sampling of farmers was done by using simple random sampling method and the data were obtained by using direct interview method with questionnaires to farmers.

The willingness to accept (WTA) value in this study was investigated by using interview techniques to farmer respondents who own agricultural land in the peri-urban areas of Pekalongan City, exploring the willingness of farmers to receive compensation in order to protect agricultural land sustainability. The willingness of farmers to receive compensation can give an idea of the extent of sustainability of agricultural land in the peri-urban areas from the side of farmers as owners and managers of agricultural land. The desire of farmers to protect agricultural land that was owned and managed voluntarily, without receiving certain compensation, depicts the level of agricultural land sustainability which is large in the periurban areas.

Testing of factors that influence farmers' decision to accept / reject compensation and factors that influence the amount of WTA desired by farmers can be done by using Heckman's twostage method. This method was used as an analytical tool due to its ability to explain well the factors that influence farmers' decisions to be willing to accept compensation or not (first stage-binary probit model) and the factors that influence the amount of compensation that farmers are willing to accept (second stage-OLS model) (Amegnaglo et al., 2017). In addition, this method was used on the grounds in which WTA data have a sample selection bias. Hence, to eliminate the occurrence of this bias. it is recommended to use Heckman's twostage method (Amare et al., 2016). In this study the Heckman's two stage method was analyzed using Eviews 9.0 software. First stage of Heckman's two-stage method used binary probit model as follows: 
$P W T A=\beta_{0}+\beta_{1} X_{1}+\beta_{2} X_{2}+\beta_{3} X_{3}+\beta_{4} X_{4}+$ $\beta_{5} X_{5}+V_{1}$

Where:

PWTA = Dummy variable (PWTA $=0$ if the farmer is willing to receive compensation, and PWTA $=1$ if the farmer is not willing to receive compensation); $\beta_{0}=$ Constants; $\beta_{1}-\beta_{5}=$ Regression coefficient; $\mathrm{X}_{1}=$ Farm income (IDR); $\mathrm{X}_{2}$ = Non-farm income (IDR); $X_{3}=$ Family burden (\%); $\mathrm{X}_{4}=$ Agricultural land distance to the main road $(\mathrm{Km}) ; \mathrm{X}_{5}=$ farmers' perception of the agricultural land sustainability (\%); $\mathrm{V}_{1}=$ Error term.

In the binary probit model as the first step of Heckman's two-stage method, the value of the Inverse Mills Ratio (IMR) variable was measured. IMR is a proxy variable for the probability of farmers received or rejected the compensation (WTA). Furthermore, in the second stage of Heckman's two-stage method, the IMR variable was used as an additional explanatory variable to produce consistent estimates on the value of farmers' WTA model. The IMR value will be a reference to determine whether the model used has a sample selection bias. IMR which is not significant at the specified alpha level indicates that the model used does not have a sample selection bias, and vice versa. If the IMR is significant, the OLS model in the second stage of Heckman's two-stage method is declared invalid (Amegnaglo et al., 2017).
The amount ofWTA value of farmers to receive compensation so that they are still willing to protect their agricultural land was obtained by asking the second question to farmers about how much money the farmers is willing to accept as compensation for protecting agricultural land sustainability. After the WTA value was known, it was analyzed by using the OLS (Ordinary Least Squares) model which is the second stage of Heckman's two-stage method. This model was used to determine the factors affecting the amounts of farmers' WTA. The model can be written in the equation as follows: $\mathrm{WTA}=\beta_{0}+\beta_{1} \mathrm{X}_{1}+\beta_{2} \mathrm{X}_{2}+\beta_{3} \mathrm{X}_{3}+\beta_{4} \mathrm{X}_{4}+\beta_{5} \mathrm{X}_{5}$ $+\beta_{6} X_{6}+\beta_{7} X_{7}+V_{2}$

Where: $\mathrm{WTA}=$ The WTA value of farmers; $\beta 0=$ Constants; $\beta 1-\beta 7=$ Regression coefficient; X1 = Farming income (IDR); X2 = Non-farm income (IDR); X3 = Family burden (\%); X4 = Agricultural land distance to the main road $(\mathrm{Km})$; X5 = farmers' perception of the agricultural land sustainability (\%); X6 = Farming experience; X7 = IMR; V2 $=$ Error term

\section{RESULTS AND DISCUSSION}

Farmers' WTA to Protect Agricultural Land in the Peri-Urban Areas of Pekalongan City

Willingness to accept compensation is a method used to determine the preferences of farmers for a natural 
and an environmental resource that they manage or they feel. Farmers' willingness to accept compensation or to protect agricultural land on the peri-urban areas of Pekalongan City will relate to the sustainability of agricultural land in the peri-urban. In this study, farmers were asked directly about their willingness to protect agricultural land that is currently owned and managed. Farmers can answer "yes" or "no". Farmers with "yes" answer were those who are willing to protect the existence of agricultural land owned and managed voluntarily without expecting a certain compensation. In addition to the "yes" answer, the farmers can answer "no", which means that the farmers are not willing to protect the agricultural land owned and managed voluntarily. The distribution of willingness of farmers to accept or reject compensation (WTA) can be seen in table 1 .

Based on table 1, it can be seen that as many as 57 respondents or 63.33 percent of farmers on the periurban areas of Pekalongan City refused to receive compensation to protect the existence of agricultural land owned and managed. This means that 63.33 percent of farmers on the peri-urban areas of Pekalongan City were willing to continue to maintain the agricultural land that was owned at that time and managed voluntarily without demanding a certain
Table 1. Distribution of Farmers' Willingness to Accept or Reject a Compensation (WTA)

\begin{tabular}{lrr}
\hline $\begin{array}{l}\text { Category of } \\
\text { Farmers' Willing }\end{array}$ & $\begin{array}{r}\text { Total } \\
\text { (Person) }\end{array}$ & $\begin{array}{r}\text { Percentage } \\
(\%)\end{array}$ \\
\hline Reject $(\mathrm{WTA}=0)$ & 57 & 63.33 \\
Accept $(\mathrm{WTA}>0)$ & 33 & 36.67 \\
\hline Total & 90 & 100.00 \\
\hline
\end{tabular}

Source: Analysis of Primary Data (2019)

Table 2. Average WTA of Farmers to Be Willing to Protect the Sustainability of Agricultural Land in the Peri-Urban Areas of Pekalongan City

\begin{tabular}{lrr}
\hline $\begin{array}{l}\text { WTA } \\
\text { Information }\end{array}$ & $\begin{array}{r}\text { WTA Value } \\
\text { (IDR / yr) }\end{array}$ & $\begin{array}{r}\text { Percentage } \\
\text { of WTA (\%) }\end{array}$ \\
\hline Initial Bid & $8,012,931.82$ & 45.45 \\
Final Bid & $7,217,827.27$ & 41.45 \\
\hline
\end{tabular}

Source: Analysis of Primary Data (2019)

compensation (rejecting the WTA). However, there were 33 respondents or 36.67 percent of farmers in the periurban areas of Pekalongan City were willing to receive compensation in return for retaining their agricultural land owned and managed. These results mean that 36.67 percent of farmers on the peri-urban areas of Pekalongan City were not willing to protect agricultural land owned and managed voluntarily, and demand compensation (receiving WTA). Thus, the existence of agricultural land on the peri-urban areas of Pekalongan City can be maintained.

Table 1 shows that most farmers on the peri-urban areas of Pekalongan City were willing to protect their agricultural 
land voluntarily, so this means that the willingness of farmers to maintain the sustainability of agricultural land in the peri-urban was included in the high category. Farmers were willing to keep maintaining agricultural land voluntarily because they consider agriculture to be the only skill they have to work, so agricultural land becomes the main source of family income and the main source of family food.

A small percentage of farmers in the peri-urban areas of Pekalongan City were not willing to maintain voluntarily agricultural land that they owned. This is because the condition of the agricultural land owned and managed by farmers had poor environmental conditions at that moment indicated by continuous intrusion of sea water and pollution of irrigation water caused by batik industry waste or the jeans industry. Farmers perceived that poor environmental conditions had caused agricultural land to become unproductive, so it did not provide benefits to farmers. Therefore, farmers wanted and were willing to receive compensation (WTA) to maintain the sustainability of agricultural land in the peri-urban areas of Pekalongan City. On the other hand, to maintain the sustainability of agricultural land in the suburbs of Pekalongan City, the government of Pekalongan Regency and Batang Regency have planned strategies to control the rate of conversion of agricultural land contained in the RPJMD (Regional Medium-Term Development Plan). These strategies are 1) Encouraging the establishment of irrigated rice fields into sustainable food agriculture land, 2) Directing the development of built-in activities on non-rice fields, 3) Encouraging farmers to cultivate food crops, 4) Revitalizing and developing irrigation networks, and 5) Increasing the productivity of agricultural land.

The amount of compensation that the farmers were desired and willing to receive was discovered by using the openended questions method and bidding method. Then, the compensation values or the optimum WTA values with which farmers were willing to accept in order to protect the agricultural land in the periurban areas of Pekalongan City can be found. The average value of WTA willing to be accepted by farmers to protect the sustainability of agricultural land in the peri-urban areas of Pekalongan City is described in table 2 .

Based on table 2, it can be seen that in the initial bid, farmers in the peri-urban areas of Pekalongan City were willing to receive an average compensation of IDR 8,012,931.82 / year. The value of the initial offer was equivalent to $45.45 \%$ of the farmer's income from the farming activities per 
year. The optimum WTA value reflected in the WTA value in the final bid of the bidding process can only decrease by four percent from the WTA value at the initial bid. Table 2 shows that the optimum WTA value that farmers were willing to accept to protect the sustainability of agricultural land in the peri-urban areas of Pekalongan City was an average of IDR 7,217,827.27 / year or equivalent to 41.45 percent of farmers' income in the peri-urban per year. Several efforts had been made by the regional government of Pekalongan Regency and Batang Regency to maintain the sustainability of agricultural land in the suburbs, namely by establishing the Pekalongan City suburbs in the regional regulation on spatial plans and areas as food crop areas. In addition, various incentives had been provided including incentives for agricultural irrigation development, facilitation of agricultural production facilities and infrastructure.

\section{Factors Affecting Farmers' Decisions to Accept or Reject Compensation (WTA)}

In this study, the factors affecting the farmers' decision to accept or reject compensation (WTA) and the factors affecting the WTA value of farmers in the peri-urban areas of Pekalongan City were analyzed by using Heckman's twostage regression model. This method was used because the sample used has the potential for sample selection bias, so to trace and avoid bias in the model used, the Heckman two-stage regression model can be used (Amare et al., 2016; Amegnaglo et al., 2017).

This method was started from the first stage by using a probit regression model. The results of the analysis of the probit regression model which is the first stage of Heckman's two-stage model can be seen in table 3 .

The variable distance of agricultural land to the main road influences on the farmers' decision to accept or reject the WTA significantly. The regression coefficient value of the variable distance of agricultural land to the main road was 0.8472 . The regression coefficient was positive, so it can be interpreted that the farther the distance of agricultural land to the main road, the greater the chance of farmers not to receive compensation (WTA). Farmers having far agricultural land from the main road had a tendency to refuse the compensation given. This can be caused by the fact that the position of land far from the main road limit the function of the land for activities or other activities (industry, trade, etc.), besides agricultural activities (Harini et al., 2012). The average distance of farmers' agricultural land on the suburbs of Pekalongan City to the main road was $0.4583 \mathrm{~km}$. The furthest agricultural 
Table 3. Factors Affecting Farmers' Decisions to Accept or Reject Compensation (WTA)

\begin{tabular}{lcrrr}
\hline $\begin{array}{l}\text { Independent } \\
\text { Variables }\end{array}$ & Expected Sign & Coefficient & Z statistic & $\begin{array}{r}\text { Prob. Z } \\
\text { statistic }\end{array}$ \\
\hline Farm income & - & $6.02 \mathrm{E}-09^{\text {ns }}$ & 0.4928 & 0.6222 \\
Non-farm income & + & $-1.24 \mathrm{E}-08^{\text {ns }}$ & -0.8999 & 0.3682 \\
Distance & + & $0.8472^{* *}$ & 2.2363 & 0.0253 \\
Family burden & + & $-0.0010^{\text {ns }}$ & -0.3850 & 0.7002 \\
Perception & + & $0.9185^{* *}$ & 2.3557 & 0.0185 \\
Constanta & $+/-$ & $0.1210^{\text {ns }}$ & 0.3065 & 0.7592 \\
McFadden R & & & & 0.1900 \\
LR statistic & & & & 10.6504 \\
Prob(LR statistic) & & & & $0.0588^{*}$ \\
H-L statistic & & & & 6.3847 \\
Prob(H-L statistic) & & & & 0.6042 \\
Obs with Dep=0 & & & & 33.0000 \\
Obs with Dep=1 & & & & 90.00000 \\
\hline Total obs & & &
\end{tabular}

Source: Analysis of Primary Data (2019)

Where: ${ }^{* *}$ significant at the error rate $5 \%(Z$-count $=1,960) ;{ }^{\text {ns }}$ not significant

land distance reached $1.5000 \mathrm{~km}$ and the closest agricultural land to the main road was only $0.0010 \mathrm{~km}$. Farmers with far agricultural land from the main road tended to be willing to maintain the farmland that they manage voluntarily by refusing compensation given. This is due to the distance of the far distance of land from the main road, making it difficult for farmers to change the function of the land they have into other functions besides agriculture.

Farmers' perceptions were obtained and determined from various stimuli originating from their environment. The stimulation rose to an assessment or view of farmers on the sustainability of agricultural land in the suburbs of Pekalongan City. In this study, farmers' perceptions were measured on a Likert scale on five dimensions of sustainability, namely the ecological dimension, the economic dimension, the social dimension, the institutional dimension, and the technological dimension. The farmers' perception variable toward the agricultural land sustainability in the peri-urban areas of Pekalongan City had a significant effect on the farmers' decision to accept or reject the WTA. The regression coefficient of the farmers' perception variable was 0.9185 . The regression coefficient value was positive ands in accordance with the expected sign. The positive regression coefficient of farmers' perception variable can be interpreted that an increase in farmers' perceptions 
of the agricultural land sustainability in the peri-urban areas of Pekalongan City can increase the chances of farmers not to receive compensation (WTA). This shows that the higher perceptions of farmers means that farmers are willing to protect the agricultural land owned and managed voluntarily, so it can encourage the sustainability of agricultural land in the peri-urban areas of Pekalongan City. Perception is defined as a person's assessment or view of various information or stimuli received from the surrounding environment (Aulifia et al., 2016; Faridhavin et al., 2016). The higher perceptions of farmers indicate that farmers' views are increasingly positive towards the sustainability of agricultural land in the peri-urban areas of Pekalongan City. Therefore, the increase in farmers' perceptions will increase the agricultural land sustainability in the peri-urban areas of Pekalongan City.

\section{Factors Affecting Farmers' Willingness} to Accept (WTA) Values to Protect Agricultural Land in the Peri-Urban Areas of Pekalongan City

The second stage of Heckman's two-stage model was to re-regress using the multiple linear regression model using the ordinary least square (OLS) method. In this model, the inverse mills ratio (IMR) was added to the model as a proxy for the probability of farmers accepting or rejecting compensation in probit regression models (table 3 ). The results of the analysis of factors that influence the willingness to accept (WTA) value of farmers to protect the agricultural land in the peri-urban of Pekalongan City can be seen in table 4 .

Table 4 it can be seen that the inverse mills ratio (IMR) variable had a significance value of t of 0.7335 . The significance value was greater than alpha $1 \%, 5 \%$, and $10 \%$. This means that there is no sample selection bias that results from the use of WTA values more than $0($ WTA $>0)$. Therefore, OLS model in the second stage of Heckman's two-stage model is useful in explaining the factors that determine the WTA values of farmers in the peri-urban areas of Pekalongan City (Amegnaglo et al., 2017).

In Table 4, it can be seen that the farm income variable had a significant influence on the amount of WTAs that farmers were willing to accept on the peri-urban areas of Pekalongan City. The regression coefficient of farm income variable was 0.6121 . Signs on the regression coefficient were positive. It means that every increase in farm income of IDR 1 will increase the amount of WTA farmers want as much as IDR 0.6121. Therefore, the greater the farmer's income, the greater the WTA desired by farmers. This result is 
not in accordance with the expectation sign that is negative. This can occur due to farmers' higher income which shows the higher level of risk that farmers must bear in carrying out farming activities in the peri-urban areas of Pekalongan City. This risk includes production risk, price risk, and so forth (Lawalata et al., 2017; Prasada et al., 2018). Therefore, farming income in this study has a positive relationship with the number of WTAs desired by farmers in order to protect the sustainability of agricultural land in the peri-urban areas of Pekalongan City. Production risk in farming activities can be overcome by participating in agricultural insurance programs, so that the risks faced by farmers can be minimized (Septian \& Anugrah, 2014; Suharyanto et al., 2015).
Variable farmers' farming experience has a significant effect on the number of WTAs that farmers are willing to accept in the peri-urban areas of Pekalongan City. The farmers' farming experience variable in the peri-urban areas of Pekalongan City had a regression coefficient of $-70,374$. The regression coefficient means that an increase in one-year farming experience will reduce the number of WTAs desired by farmers by IDR 70,374. Therefore, it can be concluded that the higher the farmers' farming experience in the peri-urban areas of Pekalongan City, the smaller of the WTAs values that are willing to be accepted by farmers. The smaller number of WTAs shows the higher level of sustainability of agricultural land in the peri-urban areas of Pekalongan City.

Table 4. Factors Affecting Farmers' Willingness to Accept (WTA) Values to Protect Agricultural Land in The Peri-Urban Areas of Pekalongan City

\begin{tabular}{lcrrr}
\hline Independen Variables & Expected Sign & Coefficient & t statistic & Prob. t statistic \\
\hline Farm income & - & $0.6121^{* * *}$ & 6.6298 & 0.0000 \\
Non-farm income & + & $0.0146^{\mathrm{ns}}$ & 0.0931 & 0.9266 \\
Distance & + & $-3,672,972^{\mathrm{ns}}$ & -0.3758 & 0.7102 \\
Family burden & + & $3,064.0^{\mathrm{ns}}$ & 0.1864 & 0.8537 \\
Perception & + & $-1,118,122^{\mathrm{ns}}$ & -0.1043 & 0.9178 \\
Farming experience & - & $-70,374^{*}$ & -1.7099 & 0.0997 \\
Inverse mills ratio (IMR) & $+/-$ & $-6,655,032^{\mathrm{ns}}$ & -0.3276 & 0.7460 \\
Constanta & $+/-$ & $5,119,521^{\mathrm{ns}}$ & 0.3443 & 0.7335 \\
$\mathrm{R}^{2}$ & & & & 0.8505 \\
Adjusted R & & & & 0.8087 \\
F statistic & & & & 20.3232 \\
\hline \hline Prob(F statistic) & & & & $0.0000^{* * *}$ \\
\hline Source: Analyis & & & & \\
\hline
\end{tabular}

Source: Analysis of Primary Data in 2019Where: ${ }^{* * *}$ significant at the error rate $1 \%$ ( $\mathrm{t}$-count $=2,84) ;{ }^{*}$ significant at the error rate $10 \%(\mathrm{t}$-count $=1,72) ;{ }^{\mathrm{ns}}$ not significant 
The increase in farming experience can reduce the number of WTA desired by farmers because the higher the farming experience of the farmers means that they will increasingly understand and realize the benefits of the agricultural land that is owned and managed. Accordingly, the sustainability of agricultural land in the peri-urban areas can be maintained.

\section{CONCLUSION AND SUGGESTION}

Based on the results and discussion, it can be concluded that the WTA of farmers to remain willing to protect the sustainability of agricultural land in the peri-urban areas of Pekalongan City is IDR 7,217,827.27 per year. Factors that influence the farmers' willingness to accept or reject compensation were the distance of agricultural land to the main road and farmers' perceptions of the sustainability of agricultural land in the peri-urban areas. Factors that influence the farmers' WTA values to be willing to protect agricultural land in the periurban areas of Pekalongan City were farm income and farming experience. The sustainability of agricultural land in the peri-urban areas of Pekalongan City can be maintained by taking into account the facilities and infrastructure needed by farmers who have agricultural land both far and close to the main road. In addition, farmers' perceptions of the sustainability of agricultural land also need to be improved by providing counseling or training to farmers related to farming activities that run in the periurban areas. Farm income should be increased by reducing production risk. The risk of production can be overcome by participating in an agricultural insurance program.

\section{ACKNOWLEDGMENT}

Thank you, the authors convey to the Education Fund Management Institute (LPDP) for their assistance, both financially and non-financially that make it possible for the authors can publish the results of research related to the farmers' willingness to accept a compensation to protect agricultural land sustainability in peri-urban areas of Pekalongan City.

\section{REFERENCES}

Amare, D., Mekuria, W., T/wold, T., Belay, B., Teshome, A., Yitaferu, B., ... Tegegn, B. (2016). Perception of local community and the willingness to pay to restore church forests: the case of Dera district, northwestern Ethiopia. Forests, Trees and Livelihoods, 25(3), 173-186. https://doi.org/1 $0.1080 / 14728028.2015 .1133330$

Amegnaglo, C. J., Anaman, K. A., Mensah-Bonsu, A., Onumah, E. E., 
\& Amoussouga Gero, F. (2017).

Contingent valuation study of the benefits of seasonal climate forecasts for maize farmers in the Republic of Benin, West Africa. Climate Services, 6(2017), 1-11. https://doi.org/10.1016/j. cliser.2017.06.007

Aragie, T., \& Genanu, S. (2017). Level and determinants of food security in North Wollo Zone (Amhara Region-Ethiopia). Journal of Food Security, 5(6), 232-247. https:// doi.org/10.12691/jfs-5-6-4

Aulifia, A., Subejo, S., \& Harsoyo, H. (2016). Persepsi anggota grup Facebook "Komunitas Hidroponik Jogja (Hi-Jo)" terhadap pengembangan hidroponik. Agro Ekonomi, 27(2), 165-182. https:// doi.org/10.22146/jae.22691

BPS. (2018). Kota Pekalongan Dalam Angka. Kota Pekalongan, Jawa Tengah: Badan Pusat Statistik Kota Pekalongan.

Chen, M., Zhang, H., Liu, W., \& Zhang, W. (2014). The global pattern of urbanization and economic growth: Evidence from the last three decades. PLOS ONE, 9(8), 1-15. https://doi.org/10.1371/ journal.pone.0103799
Faridhavin, U., Witjaksono, R., \& Harsoyo, H. (2016). Persepsi pendamping terhadap pelaksanaan Program Upsus Pajale di Daerah Istimewa Yogyakarta. Agro Ekonomi, 27(2), 197-214. https://doi. org/10.22146/jae.22700

Gardi, C., Panagos, P., Van Liedekerke, M., Bosco, C., \& de Brogniez, D. (2015). Land Take and Food Security: Assessment of land take on the agricultural production in Europe. Journal of Environmental Planning and Management, 58(5), 898-912.

Ghazouani, T. (2013). The capital structure through the Trade-Off Theory : Evidence from Tunisian firm. International Journal of Economics and Finance, 3(3), 625-636.

Guneralp, B., Lwasa, S., Masundire, H., Parnell, S., \& Seto, K. C. (2017). Urbanization in Africa : challenges and opportunities for conservation. Environmental Reearch Letters, 13(2018), 1-9.

Harini, R., Yunus, H. S., Kasto, \& Hartono, S. (2012). Agricultural land conversion: Determinants and impact for food sufficiency in Sleman Regency. Indonesian Journal of Geography, 44(2), 120133. 
Haryanto, L. I., Masyhuri, M., \& Irham. (2018). The policy analysis matrix in measuring competitiveness of maize farming system in marginal areas. Jurnal Agro Ekonomi, 29(2), 244-260.

Jiang, L., \& Zhang, Y. (2016). Modeling Urban Expansion and Agricultural Land Conversion in Henan Province, China: An Integration of Land Use and Socioeconomic Data. Sustainability, 8(9), 920. https:// doi.org/10.3390/su8090920

Jiaran, W., Moucheng, L., Lun, Y., \& Qingwen, M. (2018). Factors affecting the willingness of farmers to accept eco-compensation in the Qianxi Chestnut Agroforestry System, Hebei. Journal of Resources and Ecology, 9(4), 407-415. https://doi.org/10.5814/j. issn.1674-764x.2018.04.008

Lawalata, M., Darwanto, D. H., \& Hartono, S. (2017). Risiko Usahatani Bawang Merah di Kabupaten Bantul. Agrica (Jurnal Agribisnis Sumatera Utara), 10(1), 56-73. Retrieved from http://ojs.uma.ac.id/index.php/ agrica

Motta, R. S. da, \& Ortiz, R. A. (2018). Costs and perceptions conditioning willingness to accept payments for ecosystem services in a Brazilian Case. Ecological Economics, 147(May 2017), 333342. https://doi.org/10.1016/j. ecolecon.2018.01.032

Nyongesa, J. M., Bett, H. K., Lagat, J. K., \& Ayuya, O. I. (2016). Estimating farmers' stated willingness to accept pay for ecosystem services: Case of Lake Naivasha watershed Payment for Ecosystem Services scheme-Kenya. Ecological Processes, 5(1), 1-15. https://doi. org/10.1186/s13717-016-0059-z

Pham, V. C., Pham, T. T. H., Tong, T. H. A., Nguyen, T. T. H., \& Pham, N. H. (2015). The conversion of agricultural land in the peri-urban areas of Hanoi (Vietnam): Patterns in space and time. Journal of Land Use Science, 10(2), 224-242. https://doi.org/10.1080/174742 3X.2014.884643

Prasada, I. M. Y., Dhamira, A., \& Nugroho, A. D. (2018). Supply Response of Paddy in East Java : Policy Implications to Increase Rice Production. AGRARIS: Journal of Agribusiness and Rural Development Research, 4(2), 129-138.

Purbiyanti, E., Muhammad, Y., \& Indri, J. (2017). Konversi lahan sawah 
di Indonesia dan pengaruhnya terhadap kebijakan Harga Pembelian Pemerintah ( HPP ) gabah/beras. Jurnal Manajemen \& Agribisnis, 14(3), 209-217.

Septian, D., \& Anugrah, G. C. (2014). Perindungan petani melalui konsep asuransi pada Gabungan Kelompok Tani Desa Argorejo, Kabupaten Bantul. Jurnal Penelitian Hukum, 1(2), 92-108.

Sudirman, S. (2012). Valuasi ekonomi dampak konversi lahan pertanian di pinggiran Kota Yogyakarta. AGRIKA, 6(1), 103-125.

Suharyanto, S., Rinaldy, J., \& Ngurah Arya, N. (2015). Analisis Risiko Produksi Usahatani Padi Sawah. AGRARIS: Journal of Agribusiness and Rural Development Research, 1(2), 7077. https://doi.org/10.18196/ agr.1210

Sun, Y., \& Akiyama, T. (2018). An empirical study on sustainable agriculture land use right transfer in the Heihe River Basin. Sustainability (Switzerland), 10(2),1-13. https:// doi.org/10.3390/su10020450

Szabo, S. (2016). Urbanisation and food insecurity risks: Assessing the role of human development. Oxford Development Studies, 44(1), 28-48. https://doi.org/10.1080/1360081 8.2015.1067292

Xiangzheng, D., Zhihui, L., \& Gibson, J. (2016). A review on trade-off analysis of ecosystem services for sustainable land-use management. Journal of Geographical Sciences, 26(7), 953-968. Retrieved from http://www.geogsci. com / a r ticle / $2016 / 1009$ 637X/38416\#outline_anchor_1

Yasar, M., \& Siwar, C. (2016). Paddy Field Conversion in Malaysia : Issues and Challenges. Rona Teknik Pertanian, 9(2), 168-177. 